\title{
Attitudinal Disposition of Nigerian University Students toward Social Networking Sites
}

\author{
http://dx.doi.org/10.3991/ijet.v7i1.1677 \\ Suleiman Alhaji Ahmad \\ College of Education, Azare, Bauchi State, Nigeria
}

\begin{abstract}
Internet has consolidated into a cohesive entity and amalgamated itself as a very powerful platform that has changed the way people do things. Social Networking Sites (SNSs) cannot be underestimated or jettison because no other communication medium which has given an international and globalized audience and dimension to the world like it. Facebook, Myspace, YouTube etc each of these and many other SNSs play a vital role on interaction and communication. The access to the internet for SNSs browsing is everywhere now. It is clearly established that even politicians, influential people, corporate managers, security agencies, lecturers, school administrators, and children are using SNSs thus students as well. Most SNSs are similar to each other there is commonality in their technical features. The study seeks to find out the level of students' attitude towards SNSs usage in the selected northern Nigerian universities. Quantitatively it was found that Nigerian students have positive attitude towards the SNSs; and that there is no significant difference in terms of gender. However, differences were found significant in terms of faculties in the extent of students' attitudes toward the SNSs usage.
\end{abstract}

Index Terms-Social Networking Sites; Attitude; Facebook; Interactionism

\section{INTRODUCTION}

Historically, in 1914 the protectorates of Southern and Northern Nigeria were amalgamated with the colony of Lagos. That was done by the former British colonial governor of the region called Fredrick Lugard. That gave birth what is now known as Nigeria.

For the past few years, the internet has consolidated into a cohesive entity and amalgamated itself as a very powerful platform that has changed the way people do business, or deal and perhaps the way the people communicate and educate. This has been possible through the use of Social Networking Sites (SNSs). As such the SNSs cannot be underestimated or jettison because no other communication medium, which has given an international or, a globalized audience and dimensions to the world like it. We have seen how some electronic and printed media houses like Aljazeera, BBC, Times Magazine, and CNN have linkages with Twitter, Facebook, MySpace, and YouTube. Each of these SNS plays a vital role on communication especially during the 2008 American election [1], Iranian 2009 elections [2] and Israel/Palestinian 2009 conflict and recently the Middle East revolution crises. Online SNSs have become the universal source of information and interaction for many millions of people, at homes, at businesses, at schools, places of work or universities. The access to the internet for SNS browsing is anywherenow a day. It is done in the school computer laboratories, libraries, cafes and on mobile phones and PDAs. [5] stated that the proportion of teenagers use the mobile, $81.6 \%$ to stay in touch with friends or loved ones.

Now it is clearly established that beside students even politicians, influential people, corporate managers, security agencies, lecturers, school administrators, and children are using SNSs [6]. In Nigeria many have presence on SNSs even the current president is on Facebook just like the other prime ministers and the presidents across the globe i.e. US president. The university students' involvement in social networking sites has increased considerably. Yet the level of social network usage between the undergraduate and postgraduate students in the universities has not been ascertained clearly[3].

\section{OBJECTIVES}

The objective of this study is to find out: 1) the level of students' attitude towards SNSs usage in the selected Northern Nigerian universities.2) The difference in attitude towards SNSs in terms of gender and faculty.

\section{QUESTIONS}

Questions asked are: 1) to what extent is the students' attitude towards SNSs in Northern Nigerian universities? 2) Is there any gender difference in the extent of attitude towards SNSs among Northern Nigerian universities students? 3) Is there any variation among the faculties in terms of the attitude towards SNSs among Northern Nigerian universities students?

\section{LITERATURE}

One of the issues raised [4] was lack of theory that can explain the difference in success and failure by SNS with relevance to acceptance and usage in order to advice developers.

Symbolic interactionism, is one of the major theoretical perspectives in sociology. This perspective has a long intellectual history, beginning with the German sociologist Max Weber (1864-1920) and the American philosopher, George Mead (1863-1931). Both of them emphasized the subjective meaning of human behavior, the social process, and pragmatism.On this [7] stressed that Interactionists focus on the subjective aspects of social life, rather than on objective, macro-structural aspects of the social systems. For interactionists, humans are pragmatic actors who must continually seek to adjust their behavior to the actions of other actors in the society. Thus, the interactionist theorist sees humans as active members, and creative participants who construct their social world, not as passive, conforming objects of socialization [7]. In the same line [8]also asserts that symbolic interactionists are often 
criticized by other sociologists for being overly impressionistic in their research methods and somewhat unsystematic in their theories.

\section{A. Social Networking Sites}

Social networking sites (SNSs) can be defined according to [9] as "web-based services that allow individuals to:

1. "Construct a public or semi-public profile within a bounded system,"

2. "Articulate a list of other users with whom they share a connection," and

3. "View and traverse their list of connections and those made by others within the system. The nature and nomenclature of these connections may vary from site to site.”

Social networking has created new ways to communicate and share information. Social networking websites are being used regularly by millions of people, and it now seems that social networking will be an enduring part of everyday life.

Structurally most SNSs are similar to each other there is commonality in their technical features. It is observed [10] [11] most provides a profile which may include two specific modules, a comment section where other signed up users can leave their comments or messages, and a list of the user's friends.

\section{B. Classification of SNSs}

Some many more SNSs are said to be link to so many ideological interest or trying to promote certain creed or deceit. Many of these sites were religious, professional, cultural, and discretional and many more pornographically in nature and by content others are religious like MyChurch, Muslimdotcom and Muxlima. But Xanga, QQ, Cybrowl, Hi5, Friendster, Ockut, Jaikuand so on are general. LinkedIn is for professional and Second Life is more of a game and virtual feelings and many more others.

\section{Students' Attitudes, towards Social Networking}

An attitude as a construct is hypothetical psyche response an action or reaction. It represents individual's dislike or like for something positively or negatively. Attitude is just a decision about something. Friendship and interaction result from attitude [12].

The ability to develop new relationships seems to be a stronger feature of social networking sites. Hence, [13] showed that most of friendships that begun through these sites led to face to face meetings and continued relationships. [4][3] further assert that "the way we feel influence the way we interact therefore private attitude can enhance or damage social relation."

In similar occurrence [14] investigated the attitude towards SNSs and its usage and found gender difference where he reported female $92 \%$ and $80 \%$ male. He also reported differences in percentage in the SNSs usage among various faculty students. In her study [15] found that "gender, race and academic achievement have negatively influence student attitudes towards internet use”. In another recent study by [16] indicated that Facebook allow only people who know each other to access their profile It means everyone is likely to have any one as a friend.
It is understood from the available data from recent studies it indicates that many SNSs user students for that matter who turn to the internet or the SNSs like YouTubeand so on for pornography or social contact do so because they consistently fail to succeed socially in their own world due to the gained bad behaviors from such action [17].

\section{MEthodology}

This quantitative research designs was descriptive in nature and the 200 subjects were measured once by administering questionnaires from the six selected universities from which two from each of the three geo-political zone of the Northern region was selected by cluster sampling. The 200 sample respondents were randomly selected in consideration of various demographic characteristics such as gender and faculty. Fig. 1 and Fig. 2 show the gender distribution and their distribution according to faculty accordingly.

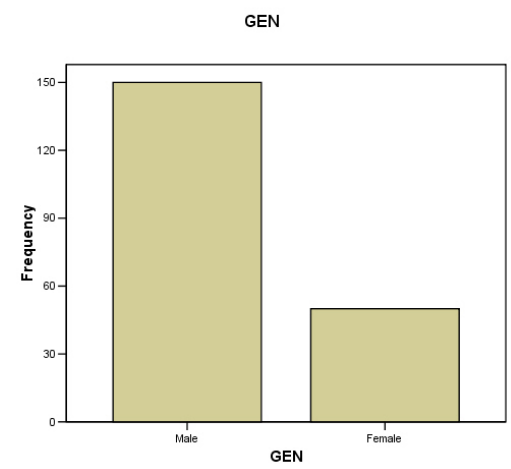

Figure 1. Distribution of respondents by gender

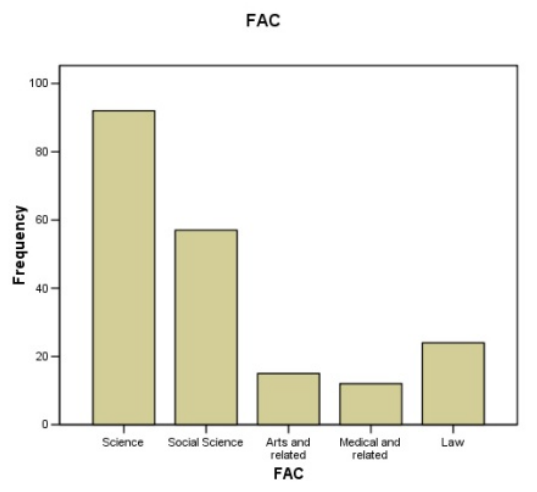

Figure 2. Distribution of respondents by faculty

Quantitative research is all about quantifying the relationships between variables. It is an established fact that such things like behavior tends to be difficult to control as it changes over time [18] pp327; [19] pp 256.

\section{RESUlts}

Question one: What is the extent of students' attitude towards SNSs in Northern Nigerian universities?

The mean distributions result and mean plot of the students' opinions with regard attitude toward using social networking sites were presented in Table 1 and Fig. 3 accordingly below. 
Question two: Is there any difference among gender in the extent of attitude towards SNSs among Northern Nigerian universities students?

In table 2 below the Independent t- test result indicates the gender differences regardingthe student's attitude toward SNSs in NorthernNigerian universities

Question three: Is there any variation among the faculties in terms of the attitude towards SNSs among Northern Nigerian universities students?Table3presents One way ANOVA result onAttitude toward SNSs among Students in Nigeria according todifferent faculties examined.Mean differences were presented in table 4 where Bonferroni test shows the differences that exist among the faculties.

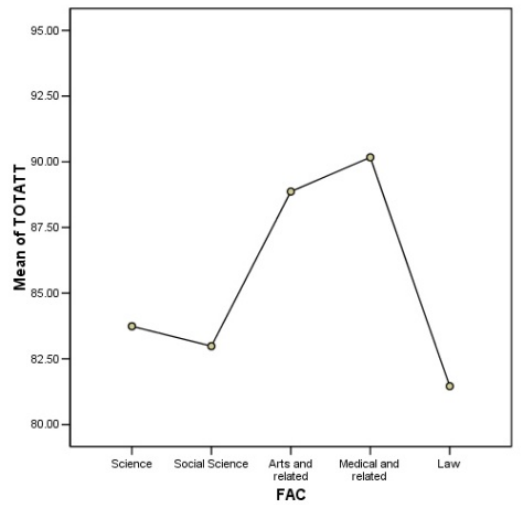

Figure 3. Mean plot of responses on total attitude by faculty

TABLE I.

EXTENT OF ATTITUDE TOWARDS SNSS AMONG NIGERIAN STUDENTS

\begin{tabular}{|c|c|c|c|c|c|c|c|c|c|c|c|c|c|}
\hline & \multirow[t]{2}{*}{$\mathbf{N}$} & \multirow[t]{2}{*}{$\mathbf{M}$} & \multirow[t]{2}{*}{ SD } & \multicolumn{2}{|c|}{ SA } & \multicolumn{2}{|c|}{ A } & \multicolumn{2}{|c|}{$\mathbf{U}$} & \multicolumn{2}{|c|}{ D } & \multicolumn{2}{|c|}{ SD } \\
\hline & & & & $N$ & $\%$ & $N$ & $\%$ & $N$ & $\%$ & $N$ & $\%$ & $N$ & $\%$ \\
\hline $\begin{array}{l}\text { I have negative attitudes and values towards } \\
\text { SNS different from that of other students in } \\
\text { this university }\end{array}$ & 200 & 2.9 & 1.3 & 37 & 18.5 & 35 & 17.5 & 49 & 24.5 & 46 & 23.0 & 33 & 16.5 \\
\hline $\begin{array}{l}\text { My interpersonal offline relationships with } \\
\text { other students have had a positive influence } \\
\text { on my personal growth, values and attitudes. }\end{array}$ & 200 & 3.6 & .99 & 31 & 15.5 & 103 & 51.5 & 37 & 18.5 & 21 & 10.5 & 8 & 4.0 \\
\hline $\begin{array}{l}\text { Since coming to this University, I have } \\
\text { developed a close personal offline relation- } \\
\text { ship with at least one lecturer. }\end{array}$ & 200 & 3.2 & 1.3 & 38 & 19.0 & 63 & 31.5 & 34 & 17.0 & 39 & 19.5 & 26 & 13.0 \\
\hline $\begin{array}{l}\text { My faculty/university is on SNS which has } \\
\text { positive influence on my studentship, } \\
\text { personality and attitudes }\end{array}$ & 200 & 3.0 & 1.1 & 27 & 13.5 & 45 & 22.5 & 53 & 26.5 & 61 & 30.5 & 14 & 7.0 \\
\hline $\begin{array}{l}\text { My SNS interactions have had a positive } \\
\text { influence on my personal growth, values, and } \\
\text { attitudes. }\end{array}$ & 200 & 3.6 & .98 & 41 & 20.5 & 86 & 43.0 & 50 & 25.0 & 17 & 8.5 & 6 & 3.0 \\
\hline $\begin{array}{l}\text { Using online social networking site allows } \\
\text { me to express my feelings clearly. }\end{array}$ & 200 & 3.6 & 1.1 & 52 & 26.0 & 77 & 38.5 & 37 & 18.5 & 25 & 12.5 & 9 & 4.5 \\
\hline $\begin{array}{l}\text { I feel SNS can be use to communicate exam } \\
\text { leakage and exam malpractice activities. }\end{array}$ & 200 & 3.2 & 1.3 & 47 & 23.5 & 49 & 24.5 & 48 & 24.0 & 24 & 12.0 & 32 & 16.0 \\
\hline $\begin{array}{l}\text { I like SNS because I seek assistance from } \\
\text { online friends about my problems }\end{array}$ & 200 & 3.6 & 1.2 & 57 & 28.5 & 78 & 39.0 & 25 & 12.5 & 24 & 12.0 & 16 & 8.0 \\
\hline $\begin{array}{l}\text { I like being independent of others when } \\
\text { browsing SNS. }\end{array}$ & 200 & 3.6 & 1.1 & 47 & 23.5 & 74 & 37.0 & 45 & 22.5 & 23 & 11.5 & 11 & 5.5 \\
\hline $\begin{array}{l}\text { It has been difficult for me to contact and } \\
\text { make friendship with other students }\end{array}$ & 200 & 2.7 & 1.2 & 21 & 10.5 & 46 & 23.0 & 36 & 18.0 & 58 & 29.0 & 39 & 19.5 \\
\hline $\begin{array}{l}\text { I prefer to always share and study with other } \\
\text { students. }\end{array}$ & 200 & 3.7 & 1.2 & 61 & 30.5 & 74 & 37.0 & 30 & 15.0 & 20 & 10.0 & 15 & 7.5 \\
\hline $\begin{array}{l}\text { Among my friends on SNS are my lecturers } \\
\text { who teach me in a class. }\end{array}$ & 200 & 2.7 & 1.3 & 25 & 12.5 & 37 & 18.5 & 37 & 18.5 & 56 & 28.0 & 45 & 22.5 \\
\hline $\begin{array}{l}\text { I am very sociable among colleagues both } \\
\text { online and offline. }\end{array}$ & 200 & 3.8 & 1.1 & 65 & 32.5 & 70 & 35.0 & 36 & 18.0 & 18 & 9.0 & 11 & 5.5 \\
\hline $\begin{array}{l}\text { Few of the students I know would be willing } \\
\text { to listen to me and help me if I had a per- } \\
\text { sonal problem. }\end{array}$ & 200 & 3.7 & 1.1 & 51 & 25.5 & 85 & 42.5 & 34 & 17.0 & 20 & 10.0 & 10 & 5.0 \\
\hline $\begin{array}{l}\text { I make friends very easily and quickly on } \\
\text { SNS more than face to face. }\end{array}$ & 200 & 3.3 & 1.3 & 52 & 26.0 & 56 & 28.0 & 27 & 13.5 & 40 & 20.0 & 25 & 12.5 \\
\hline $\begin{array}{l}\text { I use to be shy with online friends so I } \\
\text { control my interaction with them. }\end{array}$ & 200 & 2.6 & 1.2 & 17 & 8.5 & 48 & 24.0 & 31 & 15.5 & 65 & 32.5 & 39 & 19.5 \\
\hline I consider myself un popular offline. & 200 & 2.9 & 1.3 & 34 & 17.0 & 34 & 17.0 & 48 & 24.0 & 50 & 25.0 & 34 & 17.0 \\
\hline $\begin{array}{l}\text { Using SNS has a place in my religious rules, } \\
\text { regulations and injunctions. }\end{array}$ & 200 & 2.9 & 1.3 & 31 & 15.5 & 42 & 21.0 & 51 & 25.5 & 42 & 21.0 & 34 & 17.0 \\
\hline $\begin{array}{l}\text { I prefer interaction with my old friends and } \\
\text { family members on SNS than others. }\end{array}$ & 200 & 3.3 & 1.2 & 41 & 20.5 & 64 & 32.0 & 40 & 20.0 & 37 & 18.5 & 18 & 9.0 \\
\hline $\begin{array}{l}\text { I dislike using SNS often especially during } \\
\text { class hours. }\end{array}$ & 200 & 3.5 & 1.3 & 58 & 29.0 & 71 & 35.5 & 25 & 12.5 & 22 & 11.0 & 24 & 12.0 \\
\hline $\begin{array}{l}\text { In my opinion there is a need to control SNS } \\
\text { usage during class hours in this university. }\end{array}$ & 200 & 3.7 & 1.3 & 77 & 38.5 & 62 & 31.0 & 22 & 11.0 & 19 & 9.5 & 20 & 10.0 \\
\hline $\begin{array}{l}\text { SNS can be use as teaching/lecturing me- } \\
\text { dium in this university. }\end{array}$ & 200 & 3.9 & 1.1 & 79 & 39.5 & 67 & 33.5 & 25 & 12.5 & 16 & 8.0 & 13 & 6.5 \\
\hline $\begin{array}{l}\text { I am not interested in using SNS because it } \\
\text { can be use for Internet scam, dupe and fraud }\end{array}$ & 200 & 2.9 & 1.2 & 25 & 12.5 & 48 & 24.0 & 46 & 23.0 & 54 & 27.0 & 27 & 13.5 \\
\hline $\begin{array}{l}\text { Seldom use of SNS may dehumanize and } \\
\text { demoralize individual students. }\end{array}$ & 200 & 2.8 & 1.2 & 21 & 10.5 & 52 & 26.0 & 51 & 25.5 & 37 & 18.5 & 39 & 19.5 \\
\hline $\begin{array}{l}\text { Using SNS by university students has grown } \\
\text { wide that will become inevitable in the near } \\
\text { future }\end{array}$ & 200 & 3.9 & 1.1 & 87 & 43.5 & 61 & 30.5 & 25 & 12.5 & 17 & 8.5 & 10 & 5.0 \\
\hline Valid N (listwise) & 200 & & & & & & & & & & & & \\
\hline
\end{tabular}


REPORT

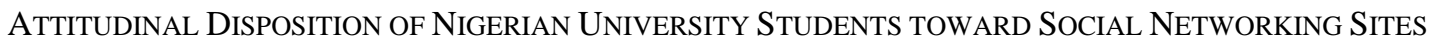

TABLE II.

GENDER DIFFERENCES AMONG NIGERIAN STUDENTS IN THE ATTITUDE TOWARDS SNSS

\begin{tabular}{|c|c|c|c|c|c|c|c|c|c|c|}
\hline & & \multicolumn{2}{|c|}{ Levene's Test } & \multicolumn{7}{|c|}{ t-test for Equality of Means } \\
\hline & & \multirow[t]{2}{*}{$\boldsymbol{F}$} & \multirow[t]{2}{*}{ Sig. } & \multirow[t]{2}{*}{$t$} & \multirow[t]{2}{*}{$d f$} & \multirow[t]{2}{*}{$\begin{array}{l}\text { Sig. (2- } \\
\text { tailed) }\end{array}$} & \multirow[t]{2}{*}{$\begin{array}{c}\text { Mean } \\
\text { Difference }\end{array}$} & \multirow[t]{2}{*}{$\begin{array}{l}\text { Std. Error } \\
\text { Difference }\end{array}$} & \multicolumn{2}{|c|}{$\begin{array}{l}\text { 95\% Confidence } \\
\text { Interval }\end{array}$} \\
\hline & & & & & & & & & Lower & Upper \\
\hline TOTATT & Equal variances assumed & 2.661 & .104 & 2.699 & 198 & .008 & 5.25333 & 1.94604 & 1.41571 & 9.09096 \\
\hline & Equal variances not assumed & & & 2.997 & 102.701 & .003 & 5.25333 & 1.75277 & 1.77701 & 8.72966 \\
\hline
\end{tabular}

TABLE III.

DIFFERENCES AMONG NIGERIAN STUDENTS IN THE ATTITUDE TOWARDS SNSS IN TERMS OF FACULTY

\begin{tabular}{|c|r|r|r|r|r|}
\hline & Sum of Squares & df & Mean Square & F & Sig. \\
\hline Between Groups & 1031.840 & 4 & 1.789 & $133^{*}$ \\
\hline Within Groups & 28122.080 & 195 & 144.216 & \\
\hline Total & 29153.920 & 199 & & \\
\hline${ }^{*}>0.05$
\end{tabular}

TABLE IV.

BONFERRONI TEST OF COMPARISON ON DIFFERENCES AMONG NIGERIAN STUDENTS IN THE ATTITUDE TOWARDS SNSS IN TERMS OF FACULTY

\begin{tabular}{|c|c|c|c|c|c|c|}
\hline \multirow{2}{*}{ (I) FAC } & \multirow{2}{*}{ (J) FAC } & \multirow{2}{*}{$\begin{array}{c}\text { Mean Differ- } \\
\text { ence (I-J) }\end{array}$} & \multirow{2}{*}{ Std. Error } & \multirow{2}{*}{ Sig. } & \multicolumn{2}{|c|}{ 95\% Confidence Interval } \\
\hline & & & & & Lower Bound & Upper Bound \\
\hline \multirow[t]{4}{*}{ Science } & Social Science & .75667 & 2.02427 & 1.000 & -4.9909 & 6.5042 \\
\hline & Arts and related & -5.12754 & 3.34394 & 1.000 & -14.6221 & 4.3670 \\
\hline & Medical and related & -6.42754 & 3.68586 & .828 & -16.8929 & 4.0378 \\
\hline & Law & 2.28080 & 2.75255 & 1.000 & -5.5346 & 10.0962 \\
\hline \multirow[t]{4}{*}{ Social Science } & Science & -.75667 & 2.02427 & 1.000 & -6.5042 & 4.9909 \\
\hline & Arts and related & -5.88421 & 3.48489 & .929 & -15.7790 & 4.0106 \\
\hline & Medical and related & -7.18421 & 3.81420 & .611 & -18.0140 & 3.6455 \\
\hline & Law & 1.52412 & 2.92217 & 1.000 & -6.7729 & 9.8211 \\
\hline \multirow[t]{4}{*}{ Arts and related } & Science & 5.12754 & 3.34394 & 1.000 & -4.3670 & 14.6221 \\
\hline & Social Science & 5.88421 & 3.48489 & .929 & -4.0106 & 15.7790 \\
\hline & Medical and related & -1.30000 & 4.65106 & 1.000 & -14.5059 & 11.9059 \\
\hline & Law & 7.40833 & 3.95264 & .624 & -3.8145 & 18.6312 \\
\hline \multirow[t]{4}{*}{ Medical and related } & Science & 6.42754 & 3.68586 & .828 & -4.0378 & 16.8929 \\
\hline & Social Science & 7.18421 & 3.81420 & .611 & -3.6455 & 18.0140 \\
\hline & Arts and related & 1.30000 & 4.65106 & 1.000 & -11.9059 & 14.5059 \\
\hline & Law & 8.70833 & 4.24582 & .416 & -3.3469 & 20.7636 \\
\hline \multirow[t]{4}{*}{ Law } & Science & -2.28080 & 2.75255 & 1.000 & -10.0962 & 5.5346 \\
\hline & Social Science & -1.52412 & 2.92217 & 1.000 & -9.8211 & 6.7729 \\
\hline & Arts and related & -7.40833 & 3.95264 & .624 & -18.6312 & 3.8145 \\
\hline & Medical and related & -8.70833 & 4.24582 & .416 & -20.7636 & 3.3469 \\
\hline
\end{tabular}

\section{DISCUSSION}

In the table 1 above out of the 25 question items asked on the attitude towards SNSs Usage item 1 (I have negative attitudes and values towards SNS.) has a very low mean= 2.9 and $\mathrm{SD}=1.3$. The item was stated negatively and the responses out of the $n=200$ indicated agree $=n 46 / 23.0 \%$ and strongly disagree $\mathrm{N}=33 / 16.5 \%$. This means majority denied having negative attitude towards SNSs usage.Another item (I am very sociable among colleagues both online and offline) has significant score of $n=65 / 32.5 \%$ as strongly agree and $n=70 / 35.0 \%$ as agree option. The item has the mean of 3.8 and the $\mathrm{SD}=1.1$. Last Item 25 (Using SNS by university students has grown wide that will become inevitable in the near future) have a higher mean $\mathrm{M}=3.9$ and SD having 1.1. This means many of the students are interested in using SNSs and are willing to continue with it. It also shows that they anticipated that the level of the usage will increase high that almost everyone will be using the SNSs among the students. It tally with [13] who showed that most of friendships that begun through these sites led to face to face meetings and continued relationships which subsequently boost the attitude towards SNSs. Many reported that SNSs have positive influence on their personal growth, values and attitudes and that it allows them to express their feelings. Although overwhelming majority admitted that there is a need to control SNS usage during class hours because to them they dislike using SNSs often especially during class hours however majority accepted having positive attitude towards SNSs usage. More so many confirmed making friends very easily and quickly on SNS more than face to face. They consider themselves very sociable among colleagues both online and offline. Therefore they prefer to always share and study with other students and believed to be seeking assistance from online friends about their academic and personal problems.

To answer the second research question the independent $t$. test conducted on gender the $n=200$ respondents show the two groups consisting of the female group of $n=50$ and the male group of $n=150$. The $t$ value has $a$ significant score of 2.6 $=.008$ significance at two tails as shown in table 2 above. The table 2 also shows the $F$ value was 2.66 with equal mean difference of .104 which shows that the $t$ value slightly differs between the groups. The overall result indicated $\mathrm{p}>0.05$ at two tailed. The magnitude of the difference was very little $=.003$. This suggests that there is no significant difference between the gender groups in the extent of attitude towards SNSs usage in the 
northern Nigerian universities. This result concurs to [15] [14] whose results also confirmed that.

On the third question the one way ANOVA was used the result (table 3) shows the description of the faculties' scores in terms of the students' attitudes towards SNS Usage. The faculty of science has the highest $n=92$. Faculty of Medical and related has the lowest $n=12$. The general ANOVA group difference as shown in the table 3above shows $\mathrm{F}=(4,257.9)=1.7$ at .133 significance. Therefore there is significance difference among the faculties because $\mathrm{p}>0.05$ (.133). Test of comparison (Table 4)also gives the difference between the individual group results against each other group. Where higher mean difference exist between medical and law while the lowest exists between the social sciences and sciences faculties.

\section{CONCLUSION}

If knowledge is power, communication is freedom. In sum, SNSs technologies such as Facebook, YouTube, MySpace and alike were found to be significantly used among students in Northern Nigerian universities. They provided such avenues for self expression especially among university students where they shared and interacted with each other. The study concluded that Northern Nigerian students significantly have high level of positive attitude towards SNSs they use SNSs to communicate and share information.It also concluded that there is no significant difference in terms of gender in the extent of SNSs usage. On the other there aresignificance differences among the faculties in the extent of SNSs usage.A number of the research limitations evident in this research can be overcome in future research. For example, there is the need to re-test these scales with a larger sample and confirmatory factor analysis this is in order to further confirm the validity of the constructs. Further studies are also required to targeting samples as unit of analysis other than university academic community.Due to fewer finance the present study was limited to only Northern Nigeria a wider area scope can be investigated to cover the whole of Nigeria.

\section{ACKNOWLEDGMENT}

Acknowledged the effort from Associate Professor Jelani Shaari, Dr. ArsaythambyVeloo and Dr Aizan Yaqub all of Universiti Utara.

\section{REFERENCES}

[1] [1]CBC News (2009). Iran Blocks Access to Facebook Ahead Of Election.Retrieved, May15, 2009 from http://www.cbc.ca/ technology/story/2009/05/25/facebook.html

[2] [2] Aljazeera, (2009). Al Jazeera Network is on Facebook. Retrieved 15 $15^{\text {th }}$ June 2009 from http://www.facebook.com/ pages/Al-Jazeera-Network/7382473689

[3] [3]Dwyer, C., Hiltz, S. R., \&Passerini, K. (2009). Trust And Privacy Concern Within Social Networking Sites: A comparison of Facebook and MySpace. Proceedings of AMCIS 2007, Keystone, CO. Retrieved April 21, 2009 from http://csis.pace.edu/ dwyer/research/DwyerAMCIS2007.pdf

[4] [4]Dwyer, C. Roxanne, H., Widmeyer, G., (2008). Understanding Development and Usage of Social Networking Sites: The Social Software Performance Model. Retrieved $5^{\text {th }}$ April 2009 from University Utara Malaysia. IEEE Xplore.

[5] [5]Gil-Pechuan, I., Albarracin-Guillem, J.M.; Palmer-Gato, Marta E.I., (2009): Antecedents, Behaviour And Consequences Of The
Use Of Social Technologies In Young People In The Autonomous Community Of Valencia: Creation Of A Global Model Of Behaviour Amongst Teenagers In The Use Of Participative Social Technologies. Retrieved from IEEE UUM 2010 UNIVERSITI UTARA MALAYSIA.

[6] [6]Waters, D., (2008). Children Flock to Social Networks.Technology editor, BBC News Website. Retrieved on $17^{\text {th }}$ June, 2009 from http://news.bbc.co.uk/2/hi/technology/73250 19.stm

[7] [7]Kent McClelland (2000). Functioalism, Conflict and Others Social Theories. Retrieved on $6^{\text {th }}$ March 2009 from http://www.polity.co.uk/jones/article.htm

[8] [8]Christian Fuchs (2009). Social Networking Sites and the SurveillanceSociety. A Critical Case Study of the Usage of studiVZ, Facebook, and MySpace by Students in Salzburg in the Context of Electronic Surveillance Salzburg/Vienna, Austria.ICT\&SCenter Research Report. Retrieved $8^{\text {th }}$ August 2009 fromhttp://fuchs.icts.sbg.ac.at/SNS Surveillance Fuchs.pdf

[9] [9]Boyd, d. m. \& Ellison, N.B. (2007). Social network sites: Definition, history, and scholarship. Journal of ComputerMediated Communication, 13(1), article 11. Retrieved from http://jcmc.indiana.edu/vol13/issue1/boyd.ellison.html

[10] [10]Lockyer Lori and PattersonJohn(2008). Integrating Social Networking Technologies In Education:ACase Study Of A Formal Learning Environment. International Conference on Advanced Learning Technologies. Retrieved on $22^{\text {nd }}$ September 2009 fromAuthorized licensed use limited to: UNIVERSITI UTARA MALAYSIA. IEEE Xplore.

[11] [11]HosioSimo, KukkaHannu, and RiekkiJukka, (2008).Leveraging Social Networking Services to Encourage Interaction in Public Spaces.MUM'2008, December 3-5, 2008, Umeå, Sweden.Retrieved $1^{\text {st }}$ March, 2010 at 4:05pm from Universiti Utara Malaysia ACM databases. 978-1-60558-192-7 08/12

[12] [12]Bertram Malle, (2009) Attitudes and Social Behavior.Psychology Lecture 1: 456/556.Retrieved on $17^{\text {th }}$ September, 2009 from http://www.uoregon.edu/ bfmalle/456/L1.html

[13] [13]Dwyer, C. (2007). Digital Relationships in the 'MySpace' Generation: Results from a Qualitative Study. Proceedings of the Fortieth Hawaii International Conference on System Sciences. Los Alamitos, CA: IEEE Press.

[14] [14]Wolfe, A.M. (2010). Student Attitudes towards Social Networking Sites and Learning Modalities.Retrieved from http://alisonwolfe.com/wordpress/wpcontent/uploads/Student Attitudes Social Networks2.pdf

[15] [15]Nik Yusuf. (2006). Student Attitudes towards the use of Internet for learning. The case study of FA UUM.UnPublished M.Sc. Thesis. UUM

[16] [16]HorngShwu-Min, (2009). The Behavior and Preferences of Users on Web 2.0 Social Network Sites: AnEmpirical Study. Sixth International Conference on Information Technology: Retrieved: August 24, 2009 from IEEE Xplore Universiti Utara Malaysia.

[17] [17]Raizada, R., Vinayak, T, Srivastav, G, Garg S, Mehorata, S., and Chandak, S., (2009). The Effect of Social Networking Sites on Personal Lives of People. A qualitative research. ICFAI IBS gurgaon. India

[18] [18]Creswell J.W., (2008). Educational research: Planning, conducting, and evaluating quantitative and qualitative research. Upper Saddle River, NJ: Pearson/Merrill Education.

[19] [19]Wiersma, W. and Jurs, S.G., (2009 $9^{\text {th }}$ edition). Research Method in Education.An Introduction. Boston. Pearson.

\section{AUTHORS}

A. A. Suleiman (PhD) is a Principal lecturer with College of Education PMB 44 Azare, Bauchi State Nigeria now working in Universiti Utara Malaysia (Northern University Malaysia) as a research fellow. (suleimanahmad81@yahoo.com)

Submitted, May, 16, 2011. Published as resubmitted by the authors 28 February 2012. 